\title{
Chemical Composition and Larvicidal Activity of Rollinia leptopetala (Annonaceae)
}

\author{
Edinilza M. A. Feitosa, ${ }^{a}$ Ângela M. C. Arriaga, ${ }^{*, a}$ Gilvandete M. P. Santiago, ${ }^{a, b}$ \\ Telma L. G. de Lemos, ${ }^{a}$ M. Conceição F. de Oliveira, ${ }^{a}$ Jackson Nunes e Vasconcelos, ${ }^{a}$ \\ Jefferson Q. Lima, ${ }^{a}$ Grazielle T. Malcher, ${ }^{a}$ Ronaldo F. do Nascimento ${ }^{c}$ and Raimundo Braz-Filho ${ }^{d}$ \\ ${ }^{a}$ Departamento de Química Orgânica e Inorgânica, Universidade Federal do Ceará, CP 6044, \\ 60455-970 Fortaleza-CE, Brazil \\ ${ }^{b}$ Departamento de Farmácia, Universidade Federal do Ceará, Rua Capitão Francisco Pedro 1210, \\ 60430-370 Fortaleza-CE, Brazil \\ ${ }^{c}$ Departamento de Química Analítica e Físico-Química, Universidade Federal do Ceará, CP 12100, \\ 60451-670 Fortaleza-CE, Brazil \\ ${ }^{d}$ Setor de Química de Produtos Naturais, LCQUI-CCT, Universidade Estadual do Norte Fluminense, \\ 28013-603 Campus-RJ, Brazil
}

\begin{abstract}
No presente trabalho descreve-se a composição química dos óleos essenciais de Rollinia leptopetala R.E. Fries (Annonaceae) e as atividades larvicidas dos óleos essenciais, do extrato metanólico das raízes desta espécie e do alcalóide oxoaporfinico, liriodenina (1), frente às larvas no terceiro estágio do mosquito Aedes aegypti. $\mathrm{O}$ extrato metanólico mostrou-se ativo com $\mathrm{CL}_{50}$ $64,6 \pm 1,5 \mathrm{ppm}$ e uma forte atividade foi exibida para o composto (1), $\mathrm{CL}_{50} 3,6 \pm 0,4 \mathrm{ppm}$. Os óleos essenciais das folhas e galhos também mostraram atividade com $\mathrm{CL}_{50} 104,7 \pm 0,2$ and $34,7 \pm 0,3 \mathrm{ppm}$, respectivamente. Estes dados sugerem que $R$. leptopetala é fonte potencial de larvicidas naturais. A composição química do óleo essencial e as atividades descritas são comunicadas pela primeira vez.
\end{abstract}

The aim of present study was to describe the chemical composition of the essential oils from the leaf and stem of Rollinia leptopetala R. E. Fries (Annonaceae) and to evaluate the larvicidal activities of these essential oils, of the methanol extract from roots of this plant and of the oxoaporphine alkaloid, liriodenine (1) against the third-instar of Aedes aegypti larvae. The methanol extract from the roots showed larvicidal activity with $\mathrm{LC}_{50} 64.6 \pm 1.5 \mathrm{ppm}$. Higher activity was observed for the isolated alkaloid liriodenine (1), $\mathrm{LC}_{50} 3.6 \pm 0.4 \mathrm{ppm}$. The essential oils from the leaves and stems, also exhibited larvicidal activity with $\mathrm{LC}_{50} 104.7 \pm 0.2$ and $34.7 \pm 0.3 \mathrm{ppm}$, respectively. These results suggest $R$. leptopetala as a source of natural larvicidal compounds. This is the first report about the chemical composition and larvicidal activity of the leaf and stem essential oils of $R$. leptopetala.

Keywords: Rollinia leptopetala, Annonaceae, essential oils, liriodenine, Aedes aegypti

\section{Introduction}

Aedes aegypti is the principal mosquito vector of dengue fever, including the hemorrhagic form, which is endemic to South East Asia, Central and South America, and West Africa. ${ }^{1}$ Between 50 and 100 million of cases are registered each year, causing thousands of deaths. ${ }^{2}$ The disease has high levels of mortality, and also inflicts

*e-mail: angelamcarriaga@yahoo.com.br great economic losses and social disruption in Brazil. ${ }^{3}$ Although some viral diseases, such as yellow fever, have been brought reasonably under control with a vaccine, no vaccine is so far available for dengue. Today, the only way of decreasing the incidence of this disease is by controlling the Aedes aegypti proliferation. This is not an easy task because the mosquitoes have developed resistance to the current synthetic insecticides that, in addition, are toxic to humans and the environment. The mosquito population control in the larval stage is much easier than in the adult 
stage, and then new strategies are needed for controlling the proliferation of the larvae of A. aegypti. Several studies have focused on natural products as insecticides for controlling A. aegypti larvae. Alkaloids and essential oils from herbal plants have demonstrated larvicidal activity, ${ }^{4-8}$ which motivated our group to search for new insecticides from Brazilian plants.

Rollinia leptopetala R. E. Fries, popularly known as pinha brava, is an endemic shrub in Brazil and shows strong toxicity when eaten by animals. ${ }^{9}$ The phytochemical investigation of Rollinia species has been reported in the literature revealing acetogenins, steroids, lignans and alkaloids, as secondary metabolites. ${ }^{10-13}$ Previous studies on liriodenine showed prominent antibacterial and cytotoxic biological activities..$^{14,15}$ In this paper, the larvicidal activities of $R$. leptopetala and of the alkaloid liriodenine (1) against the larvae of Aedes aegypti are reported.

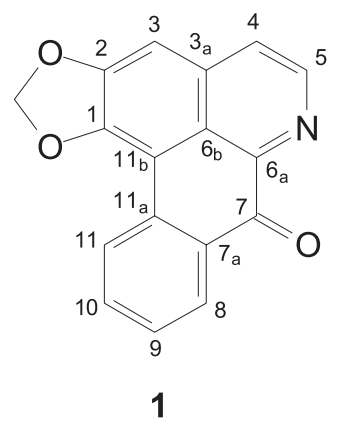

\section{Results and Discussion}

The methanol extract from the roots of $R$. leptopetala showed activity against A.aegypti larvae with $\mathrm{LC}_{50}$ $64.6 \pm 1.5 \mathrm{ppm}$. Fractionation of this extract by column chromatography gave the alkaloid liriodenine (1), which was identified by comparing its NMR and MS data with those previously reported in the literature. . $^{13,16-18}$

The alkaloid was evaluated and showed strong larvicidal activity against $A$. aegypti, with $\mathrm{LC}_{50} 3.6 \pm 0.4 \mathrm{ppm}$. Although no similar investigation was found in the literature for oxoaporphine alkaloids, some nitrogenated compounds have been presented as promising larvicides. ${ }^{19-22}$

The chemical composition of the essential oils from the leaves and stems of $R$. leptopetala showed quantitative and qualitative variation. The leaf oil consisted mainly of oxygenated monoterpenes $(47.7 \%)$, with linalool and 1,8 -cineole as the major compounds. The stem oil was devoid of monoterpenes, whereas sesquiterpenes, mainly oxygenated, were abundant (76.2\%). Spathulenol (63.9\%) was found in high concentration. The retention indices and relative percentages of the constituents of the oils are shown in Table 1.
Table 1. Chemical composition of essential oils from Rollinia leptopetala

\begin{tabular}{lccc}
\hline Constituents $^{\mathrm{a}}$ & Retention index & Leaves \% & Stems \% \\
\hline$\alpha$-Thujene & 930 & 1.4 & - \\
$\alpha$-Pinene & 939 & 4.9 & - \\
$\beta$-Pinene & 979 & 2.6 & - \\
Myrcene & 991 & 3.0 & - \\
1,8 -Cineole & 1031 & 16.5 & - \\
$\beta$-Ocimene & 1037 & 3.4 & - \\
$\alpha$-Terpinolene & 1089 & 1.1 & - \\
Linalool & 1097 & 18.7 & - \\
$\alpha$-Terpineol & 1189 & 10.4 & - \\
Geraniol & 1253 & 2.1 & - \\
$\beta$-Caryophyllene & 1419 & 5.0 & 9.3 \\
Bicyclogermacrene & 1500 & 7.6 & 14.4 \\
$\delta$-Cadinene & 1523 & 0.5 & - \\
Germacrene B & 1561 & 1.6 & - \\
Spathulenol & 1578 & 1.1 & 63.9 \\
Caryophyllene oxide & 1583 & - & 3.0 \\
Globulol & 1585 & - & 5.2 \\
Guaiol & 1601 & 0.7 & \\
epi- $\alpha$-Muurolol & 1642 & - & 4.1 \\
Total & & 80.6 & 99.9 \\
Monoterpenes \% & & 64.1 & 0 \\
Sesquiterpenes \% & & 16.5 & 99.9 \\
\hline Consitur & & &
\end{tabular}

${ }^{\mathrm{a}}$ Constituents listed in order of elution of DB-5 column.

The essential oil from the leaves showed moderate activity against the third-instar of Aedes aegypti larvae $\left(\mathrm{LC}_{50} 104.7 \pm 0.2 \mathrm{ppm}\right)$ but higher larvicidal activity $\left(\mathrm{LC}_{50} 34.7 \pm 0.3 \mathrm{ppm}\right)$ was found for essential oil from the stems, which confirmed a higher concentration of oxygenated sesquiterpenes. As no reports on the larvicidal activity were found for spathulenol, and this sesquiterpene was not isolated from the oil to be assayed, we can not suggest the higher activity found in the essential oil from stems is associated to spathulenol.

The quite high larvicidal activity of liriodenine (1) suggests this alkaloid as a model for development of new insecticides for A. aegypti control. The biological activity found for the essential oils, particularly for the essential oil from the stems, corroborates the importance of the investigation of essential oils from plants as potential insecticides and larvicides for controlling Aedes mosquitoes. ${ }^{5,8,23}$

\section{Experimental}

\section{Plant material}

R. leptopetala was collected, at the flowering stage, in Guaraciaba do Norte, in the Northeast of Brazil, in February 
2004. The plant was identified by Dr. F. S. Cavalcanti and Prof. E. P. Nunes from the Herbário Prisco Bezerra (EAC), Universidade Federal do Ceará, Brazil where a voucher specimen, \# 33496, is deposited.

\section{Extraction and isolation of liriodenine (1)}

The air-dried and pulverized roots $(500 \mathrm{~g})$ of $R$. leptopetala were washed with $20 \%$ (v/v) aqueous $\mathrm{NH}_{4} \mathrm{OH}$, and extracted with $\mathrm{CH}_{2} \mathrm{Cl}_{2}$ in a Soxhlet apparatus. The organic solution was distilled under reduced pressure giving a brown viscous syrup (50 g). This material was chromatographed on a silica gel column (63-200 $\mu \mathrm{m}$, Vetec), previously washed with $\mathrm{NaHCO}_{3}$, and eluted with a gradient system $(0 \rightarrow 30 \%)$ of $\mathrm{CH}_{2} \mathrm{Cl}_{2} / \mathrm{MeOH}$. Fractions were pooled according to TLC analysis. From the combined fractions eluted with an 80:20 mixture of $\mathrm{CH}_{2} \mathrm{Cl}_{2}: \mathrm{MeOH}$, a residue was obtained which was submitted to exclusion chromatography on Sephadex ${ }^{\mathrm{TM}}$ LH-20 (Amersham Biosciences, Sweden) by elution with a mixture of $\mathrm{MeOH} / \mathrm{CH}_{2} \mathrm{Cl}_{2}$ to yield liriodenine $(\mathbf{1}, 78.0 \mathrm{mg}, 0.16 \%$ yield $), 278.0-280.4^{\circ} \mathrm{C}$. Liriodenine (1) was also isolated from the methanol extract (18.5 g) of the roots $(500 \mathrm{~g})$, which was obtained by extraction of roots with cold $\mathrm{MeOH}$ for $72 \mathrm{~h}$ at room temperature. This material was chromatographed on a silica gel column (63-200 $\mu \mathrm{m}$, Vetec) using hexane, $\mathrm{CHCl}_{3}$, EtOAc and $\mathrm{MeOH}$ as eluents. The combined fractions eluted with $\mathrm{CHCl}_{3}$ (2.23 g) were chromatographed using a gradient system $(0 \rightarrow 30 \%)$ of $\mathrm{CH}_{2} \mathrm{Cl}_{2} / \mathrm{MeOH}$. The fractions pooled with $\mathrm{CH}_{2} \mathrm{Cl}_{2} / \mathrm{MeOH}(90: 10 \mathrm{v} / \mathrm{v})$, provided $\mathbf{1}$ (12.7 $\mathrm{mg}, 0.07 \%$ yield). Recrystallization of $\mathbf{1}$ was from $\mathrm{MeOH}$ and structural determination was performed by spectral analysis, including comparison with literature data. ${ }^{16} \mathrm{H}$ and ${ }^{13} \mathrm{C}$ NMR spectra were recorded on a Bruker Advance DRX 500 spectrometer and the mass spectrum was obtained from a VG Auto M Spec Fisions Instruments spectrometer.

\section{Essential oil isolation and chemical analysis}

The oils from the fresh leaves $(500 \mathrm{~g})$ and stems $(500 \mathrm{~g})$ of $R$. leptopetala were extracted by hydrodistillation for $4 \mathrm{~h}$, using a modified Clevenger-type apparatus with a water-cooled oil receiver to reduce distillation overheating artifacts. Pale yellowish oils were obtained in 0.03 and $0.05 \%$ yield from the leaves and stems, respectively, which were dried over anhydrous sodium sulfate and kept at $4{ }^{\circ} \mathrm{C}$ until GC-MS and GC analysis.

The essential oil constituents were quantified by Analytical GC-FID, that was carried out on a Shimadzu GC17A gas chromatograph using dimethylpolysiloxane DB-5 fused silica capillary column $(30 \mathrm{~m} \times 0.25 \mathrm{~mm} \times 0.25 \mu \mathrm{m}$ film thickness). Hydrogen was used as carrier gas at a flow rate of $1 \mathrm{~mL} \mathrm{~min}^{-1}$ and 30 psi inlet pressure; split, 1:30; temperature programmed, $35-180{ }^{\circ} \mathrm{C}$ at $4{ }^{\circ} \mathrm{C} \mathrm{min}-1$, then heated at a rate of $17^{\circ} \mathrm{C} \mathrm{min}{ }^{-1}$ to $280{ }^{\circ} \mathrm{C}$ and held isothermal for $10 \mathrm{~min}$; injector temperature, $250^{\circ} \mathrm{C}$; detector used FID, detector temperature, $250{ }^{\circ} \mathrm{C}$. The analysis of the oils was performed by GC-MS analysis on a Hewlett-Packard 5971 GC-MS instrument employing the following conditions: column: dimethylpolysiloxane DB-5 fused silica capillary column (30 $\mathrm{m} \times 0.25 \mathrm{~mm} \times 0.1 \mu \mathrm{m}$ film thickness $)$; carrier gas: helium $\left(1 \mathrm{~mL} \mathrm{~min}^{-1}\right)$; injector temperature: $250{ }^{\circ} \mathrm{C}$; detector temperature: $200{ }^{\circ} \mathrm{C}$; column temperature: $35^{\circ}-180{ }^{\circ} \mathrm{C}$ at $4{ }^{\circ} \mathrm{C} \mathrm{min}-1$ then $180-250{ }^{\circ} \mathrm{C}$ at $10{ }^{\circ} \mathrm{C} \mathrm{min}{ }^{-1}$; mass spectra: electron impact $70 \mathrm{eV}$. Individual components were identified using the Wiley L-built library and two other computer libraries ${ }^{24,25}$ MS searches using retention indices as a pre-selection routine, as well as by visual comparison of the fragmentation patterns with those reported in the literature. ${ }^{26,27}$ No linear retention index was calculated and no standard was used. The chemical components identified in the essential oils are presented in Table 1.

\section{Screening for larvicidal activity}

Liriodenine (1), essential oils, and the methanol extract were placed in beakers $(50 \mathrm{~mL})$ and dissolved in $\mathrm{H}_{2} \mathrm{O} / \mathrm{DMSO} 1.5 \%(\mathrm{v} / \mathrm{v})$ at concentrations of 1-500 ppm, followed by the addition of 50 larvae at the third-instar. For each experiment, both positive (Temephos ${ }^{\circledR}$ at $3.22 \mathrm{ppm}$ ) and negative (distilled water containing $1.5 \%$ DMSO) control assays were carried out. Mortality was recorded after $24 \mathrm{~h}$ of exposure, during which no nutritional supplement was added. The experiments were carried out at $28 \pm 2{ }^{\circ} \mathrm{C}$. Each test was performed in triplicate. Data were evaluated through regression analysis. From regression line, the $\mathrm{LC}_{50}$ values were read representing the lethal concentration for $50 \%$ larval mortality of $A$. aegypti. The bioassays were performed at the Laboratório de Entomologia, Núcleo de Endemias, Secretaria de Saúde do Estado do Ceará, Brazil.

\section{Acknowledgments}

Authors are indebted to Olga Ramos (Parque de Desenvolvimento Tecnológico do Ceará) for recording the GC-MS data, to Laboratório de Entomologia - Núcleo de Endemias da Secretaria de Saúde do Estado do Ceará for providing larvae, and to FUNCAP, FAPERJ, CAPES and $\mathrm{CNPq}$ for financial support and fellowship research (CNPq). 


\section{Supplementary Information}

Supplementary information are available free of charge at http://jbcs.sbq.org.br, as PDF file.

\section{References}

1. Ciccia, G.; Coussio, J.; Monguelli, E.; J. Ethnopharmacol. 2000, 72,185 .

2. Huber, K.; Loan, L. L.; Chantha, N.; Failloux, A.B.; Acta Tropica 2004, 90, 23.

3. Lourenço-de-Oliveira, R.; Vazeille, M.; Filippis, A. M. B.; Trans. Roy. Soc. Trop. Med. Hyg. 2004, 98, 43.

4. François, G.; Van-Looveren, M.; Timperman, G.; Chimanuka, B.; Aké-Assi, L.; Holenz, J.; Bringmann, G.; J. Ethnopharmacol. 1996, 54, 125

5. Cavalcanti, E. S. B.; Moraes, S. M.; Lima, M. A. A.; Santana, E. W. P.; Mem. Inst. Oswaldo Cruz 2004, 99, 541.

6. Cheng, S. S.; Chang, H.; Chang, S.; Tsai, K.; Chen, W.; Bioresour. Technol. 2003, 89, 99.

7. Kim, S. I.; Shin, O. K.; Song,C.; Cho, K. I.; Ahn, Y. J.; Agric. Chem. Biotechnol. 2001, 44, 23.

8. Simas, N. K.; Lima, E. C.; Conceição, S. C.; Kuster, R. M.; Oliveira Filho A. M.; Lage, C. L. S.; Quim. Nova 2004, 27, 46.

9. Maas, P. J. M.; Vestra, L. Y. T.; Flora Neotropica. Monograph 57, Organization for Flora Neotropica, The New York Botanical Garden: New York, 1992.

10. Sette, I. M. F.; da-Cunha, E. V. L.; Barbosa-Filho, J. M.; Agra, M. F.; Silva, M. S.; Biochem. Syst. Ecol. 2000, 28, 393.

11. Sette, I. M. F.; da-Cunha, E. V. L.; Barbosa-Filho, J. M.; Silva, M. S.; Pharm. Biol. 2000, 38, 318.

12. Mesquita, L. M.; Roque, N. F.; Quintana, L. M. B.; Paulo, M. Q.; Barbosa-Filho, J. M.; Biochem. Syst. Ecol. 1988, 16, 379.

13. Rao, J. U. M.; Giri, G. S.; Hanumaiah, T.; Rao, V. J.; J. Nat. Prod. 1986, 49, 346.
14. Rahman, M. M.; Lopa, S. S.; Sadik, G.; Rashid, H.; Islam, R.; Khondkar, P.; Alam, A. H. M. K.; Rashid, M.A.; Fitoterapia 2005, 76, 758.

15. Hsieh, T. J.; Liu, T. Z.; Chern, C. L.; Tsao, D. A.; Lu, F. J.; Syu, Y. H.; Chang, T. T.; Chen, C. H.; Food Chem. Toxicol. 2005, 43, 1117.

16. Nissanka, A. P. K.; Karunaratne, V.; Bandara, B. M. R.; Kumar, V.; Nakanishi, T.; Nishi, M.; Inada, A.; Tillekeratne, L. M. V.; Tillekeratne, L. M. V.; Phytochemistry 2001, 56, 857.

17. Khan, M. R.; Kihara, M.; Omoloso, A. D.; Fitoterapia 2002, 73,744 .

18. Zang Z.; Elsohly H. N.; Jacob M. R.; Pasco D. S.; Walker L. A.; Clark A. M.; J. Nat. Prod. 2002, 65, 856.

19. Begum, N. A.; Choudhury, D. N.; Banerji, J.; Das, B. P.; J. Indian Chem. Soc. 2005, 82, 165.

20. Mungkornasawakul, P.; Pyne, S. G.; Jatisatienr, A.; Supyen, D.; Jatisatienr, C.; Lie, W.; Ung, A. T.; Skelton, B. W.; White, A. H.; J. Nat. Prod. 2004, 67, 675.

21. Jiwajinda, S.; Hirai, N.; Watanabe, K.; Santisopasri, V.; Chuengsamarnyart, N.; Koshimizu, K.; Ohigashi, H.; Phytochemistry 2001, 56, 693.

22. Yang, Y. C.; Lee, S. G.; Lee, H. K.; Kim, M. K.; Lee, S. H.; Lee, H. S.; J. Agric. Food. Chem. 2002, 50, 3765.

23. Costa, J. G. M.; Pessoa, O. D. L.; Menezes, E. A.; Santiago, G. M. P.; Flavour Fragr. J. 2004, 19, 529.

24. Craveiro, A. A.; Matos, F. J. A.; Alencar, J. W.; J. Nat. Prod. 1984, 47, 890.

25. Alencar, J. W.; Craveiro, A. A.; Matos, F.J.A.; Machado, M.I.L.; Quim. Nova 1990, 13, 282.

26. Adams R. P.; Identification of Essential Oils Components by Gas Chromatography/Quadrupole Mass Spectroscopy, Allured Publ. Corp.: Carol Stream, Illinois, 2001.

27. Stenhagen E.; Abrahamson S.; Lafferty, F. W.; Registry of Mass Spectra Data, John Wiley \& Sons: New York, 1976.

Received: June 21, 2006

Web Release Date: December 4, 2008 


\title{
Chemical Composition and Larvicidal Activity of Rollinia leptopetala (Annonaceae)
}

\author{
Edinilza M. A. Feitosa, ${ }^{a}$ Angela M. C. Arriaga, ${ }^{*, a}$ Gilvandete M. P. Santiago, ${ }^{a, b}$ \\ Telma L. G. de Lemos, ${ }^{a}$ M. Conceição F. de Oliveira, ${ }^{a}$ Jackson Nunes e Vasconcelos, ${ }^{a}$ \\ Jefferson Q. Lima, ${ }^{a}$ Grazielle T. Malcher, ${ }^{a}$ Ronaldo F. do Nascimento ${ }^{c}$ and Raimundo Braz-Filho ${ }^{d}$ \\ ${ }^{a}$ Departamento de Química Orgânica e Inorgânica, Universidade Federal do Ceará, CP 6044, \\ 60455-970 Fortaleza-CE, Brazil \\ ${ }^{b}$ Departamento de Farmácia, Universidade Federal do Ceará, Rua Capitão Francisco Pedro 1210, \\ 60430-370 Fortaleza-CE, Brazil \\ ${ }^{c}$ Departamento de Química Analítica e Físico-Química, Universidade Federal do Ceará, CP 12100, \\ 60451-670 Fortaleza-CE, Brazil \\ ${ }^{d}$ Setor de Química de Produtos Naturais, LCQUI-CCT, Universidade Estadual do Norte Fluminense, \\ 28013-603 Campus-RJ, Brazil
}

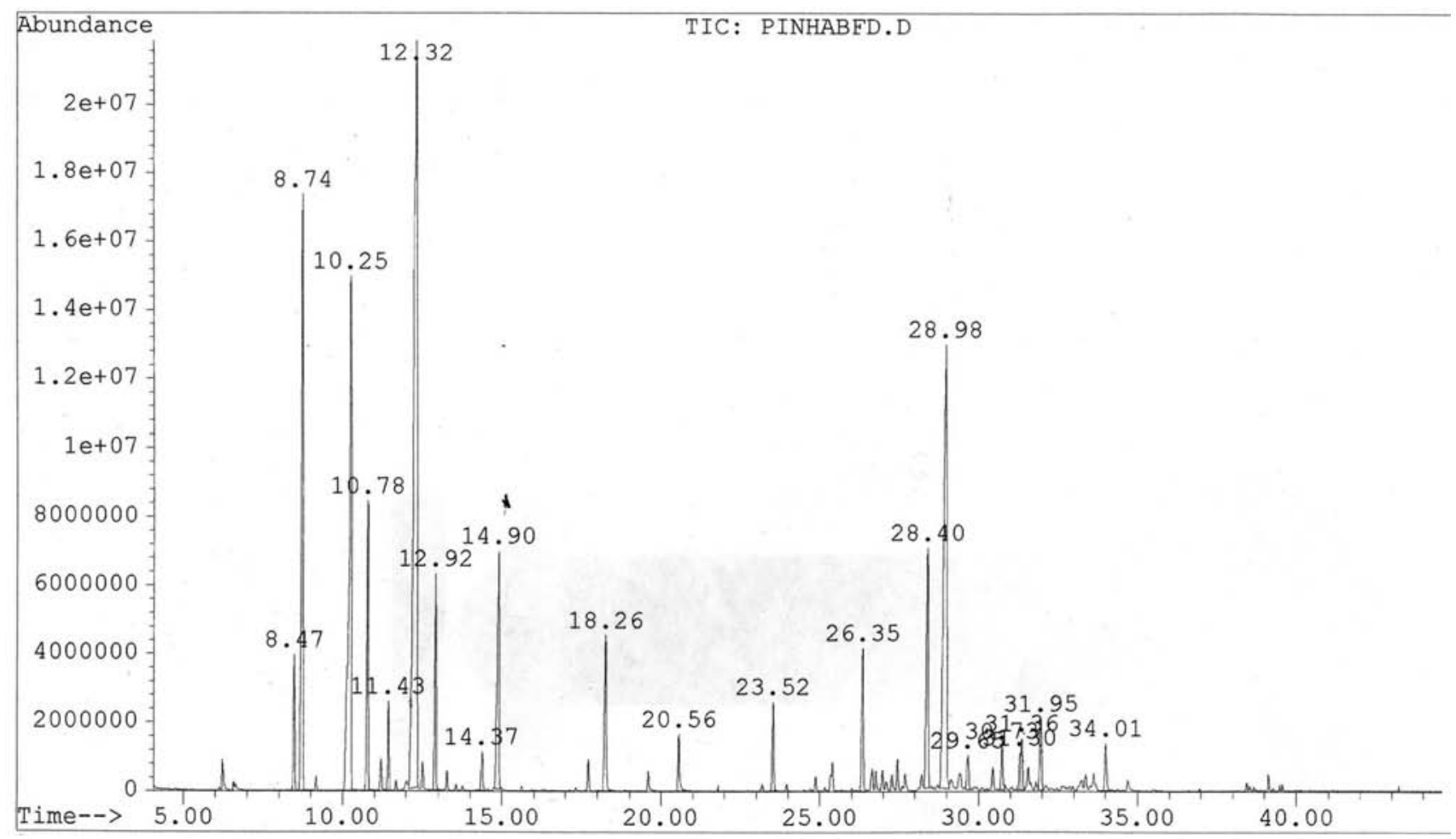

Figure S1. GC-MS chromatogram of the essential oil from leaves of Rollinia leptopetala. 


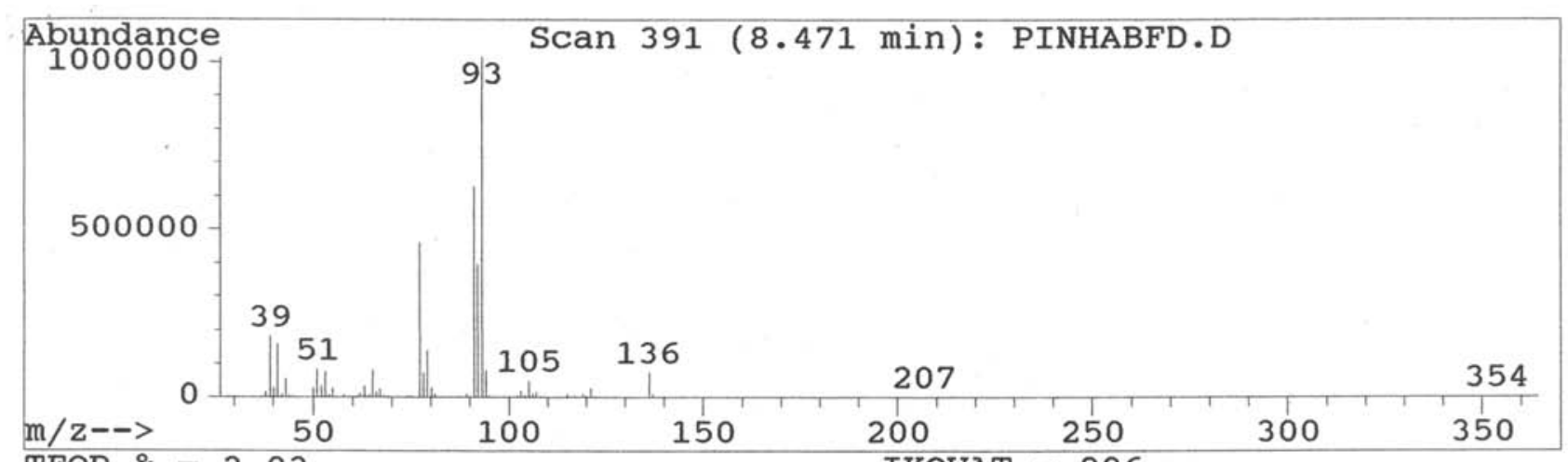

TEOR \% $=2.03$

IKOVAT $=906$

Figure S2. Mass spectra of $\alpha$-thujene.

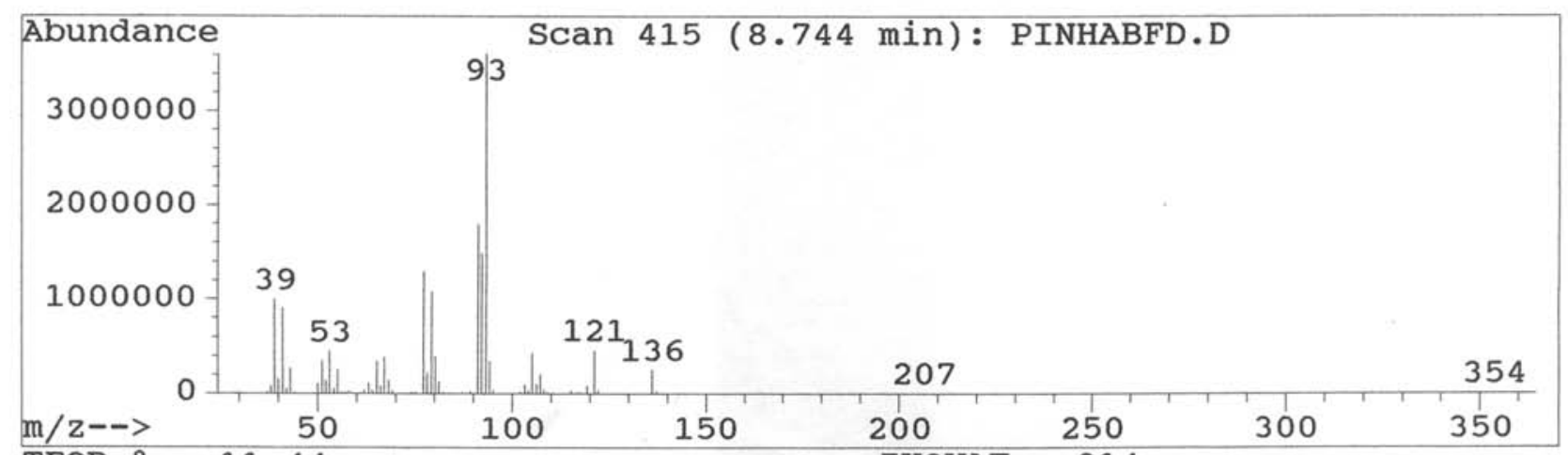

TEOR \% $=11.44$

IKOVAT $=914$

Figure S3. Mass spectra of $\alpha$-pinene.

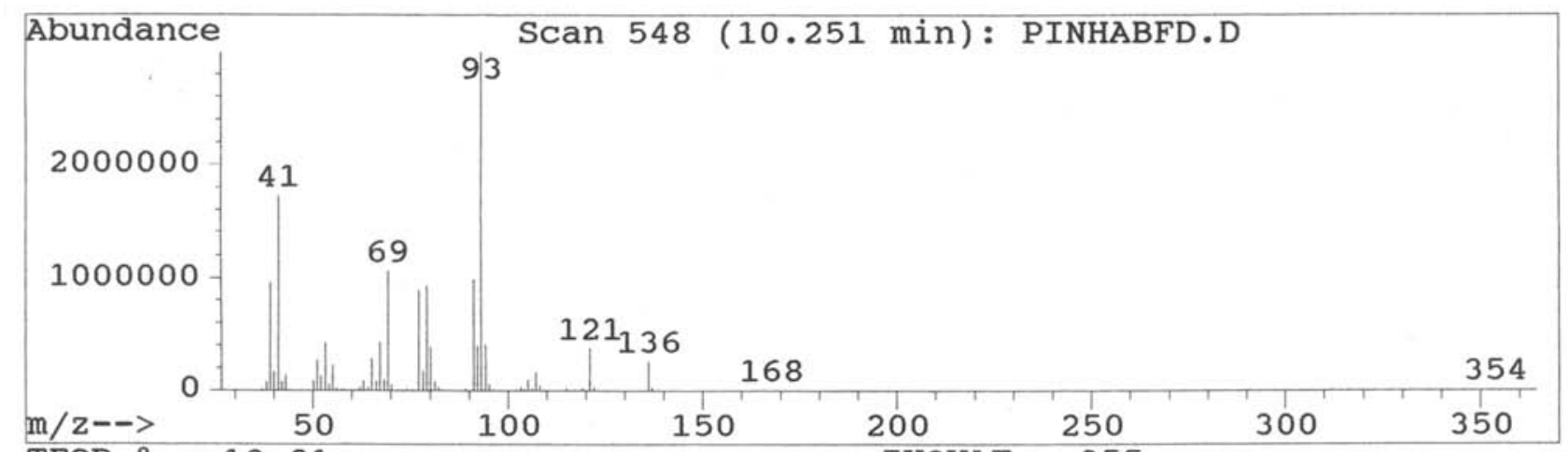

TEOR \% $=12.81$ IKOVAT $=955$

Figure S4. Mass spectra of $\beta$-pinene. 


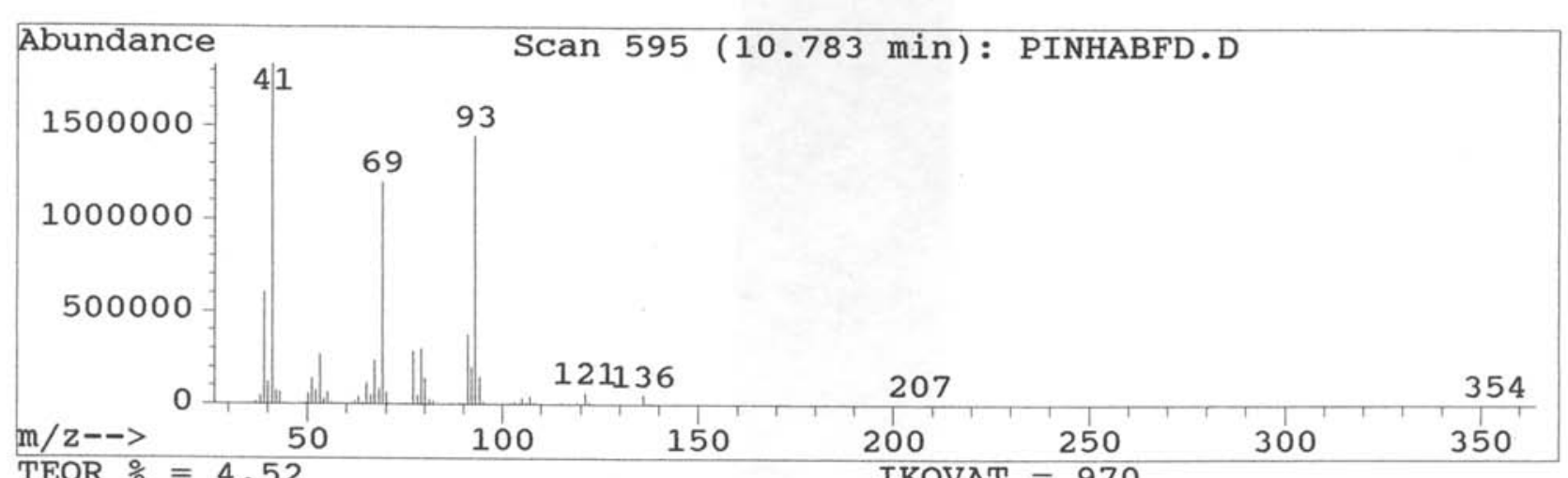

TEOR \% $=4.52$

IKOVAT $=970$

Figure S5. Mass spectra of $\beta$-myrcene.

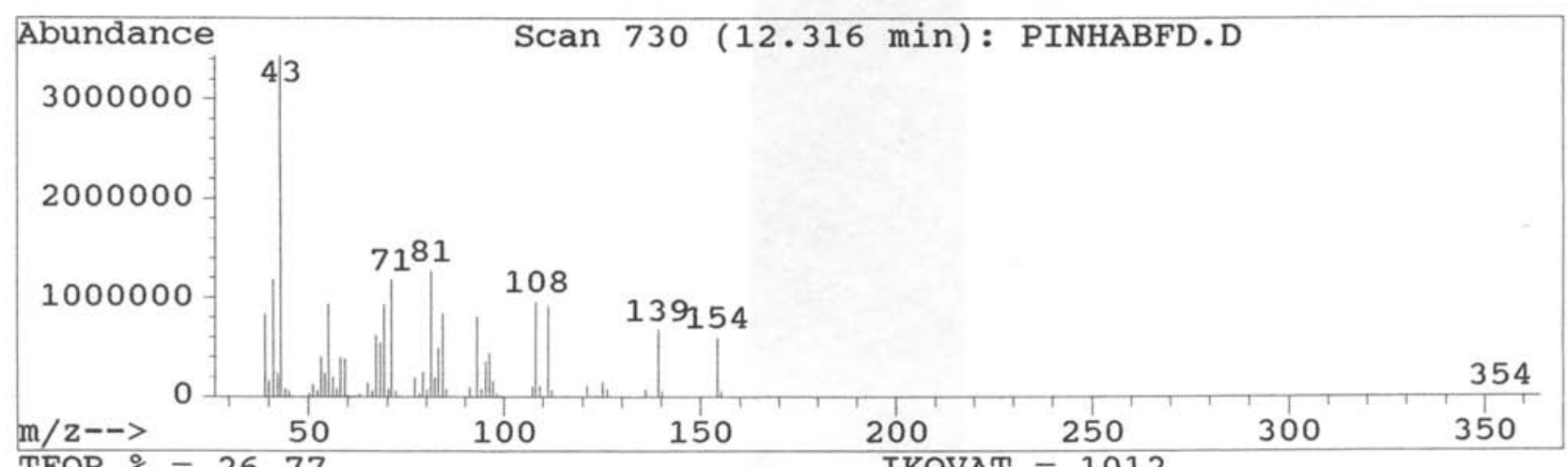

TEOR \% $=26.77$

Figure S6. Mass spectra of 1,8-cineole.

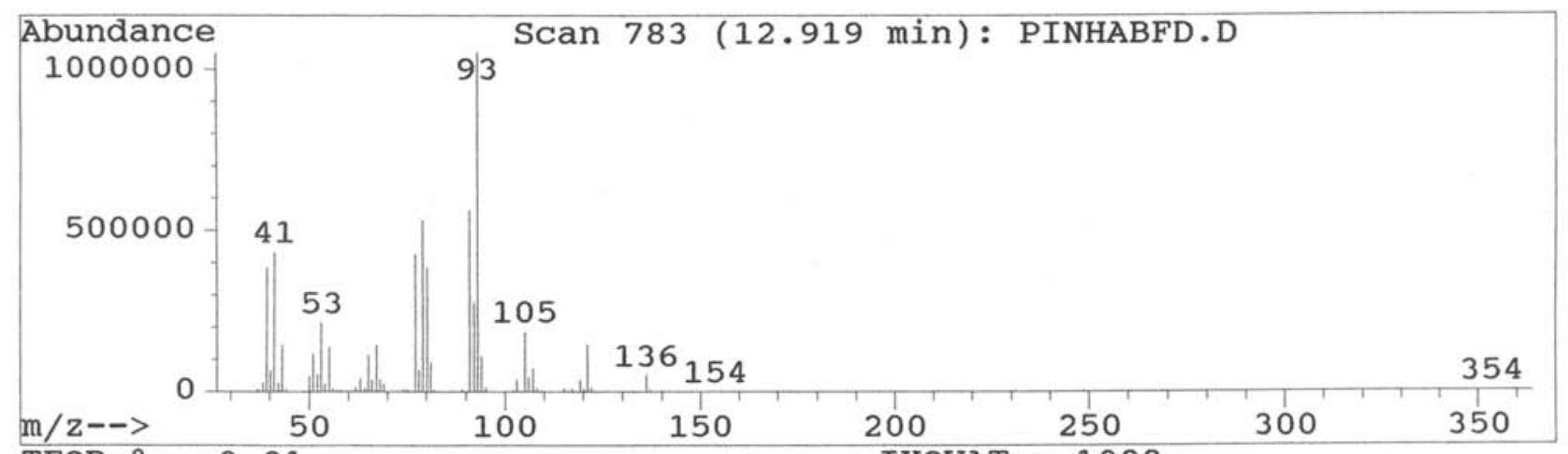

TEOR \% $=3.21$

IKOVAT $=1028$

Figure S7. Mass spectra of $\beta$-ocimene. 


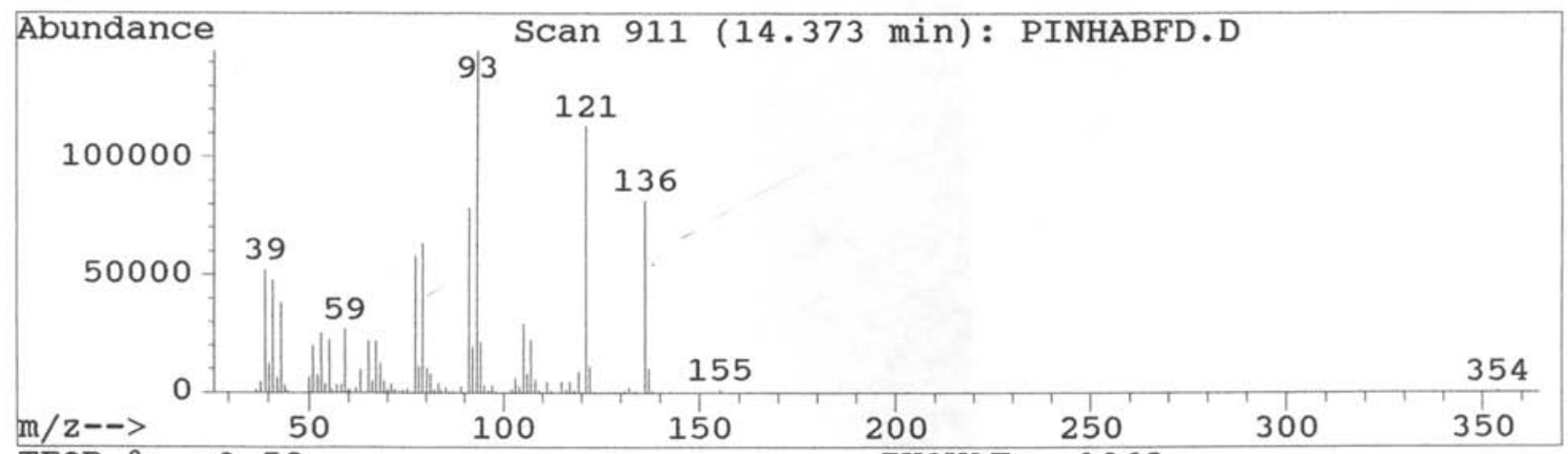

TEOR \% $=0.58$

IKOVAT $=1068$

Figure S8. Mass spectra of $\alpha$-terpinolene.

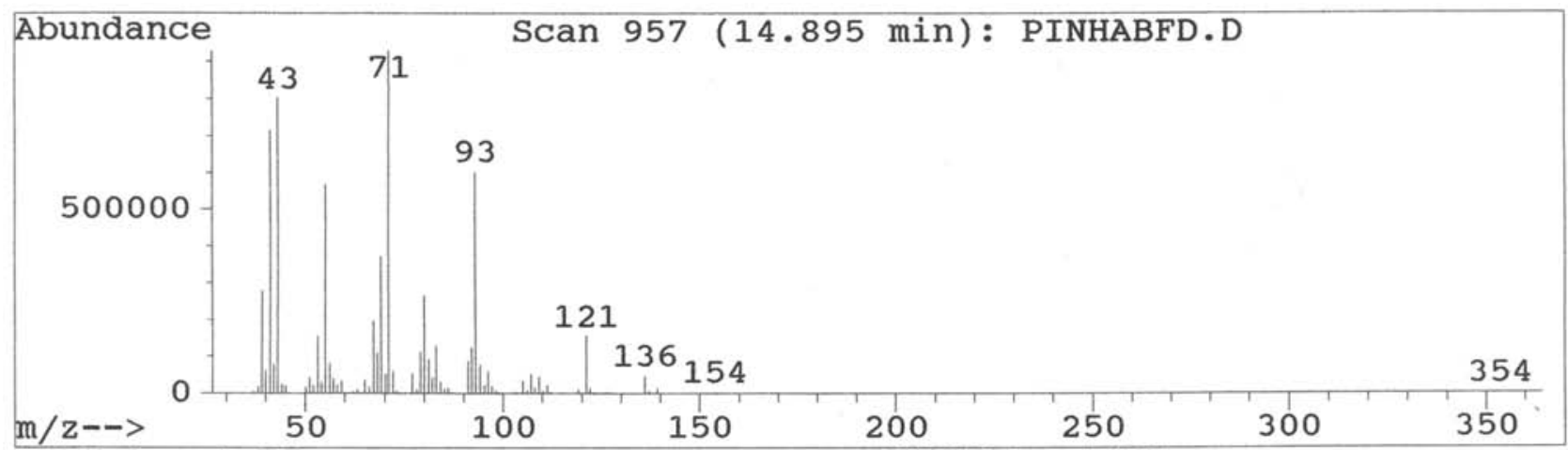

TEOR \% $=4.87$

IKOVAT $=1082$

Figure S9. Mass spectra of linalool.

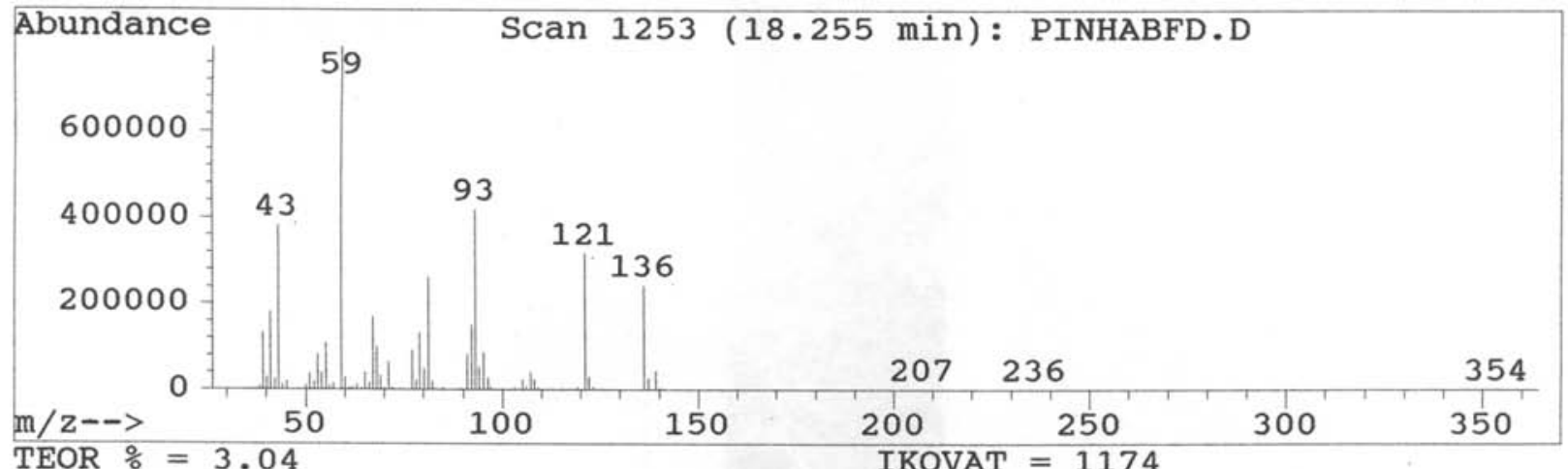

TEOR \% $=3.04$

IKOVAT $=1174$

Figure S10. Mass spectra of $\alpha$-terpineol. 


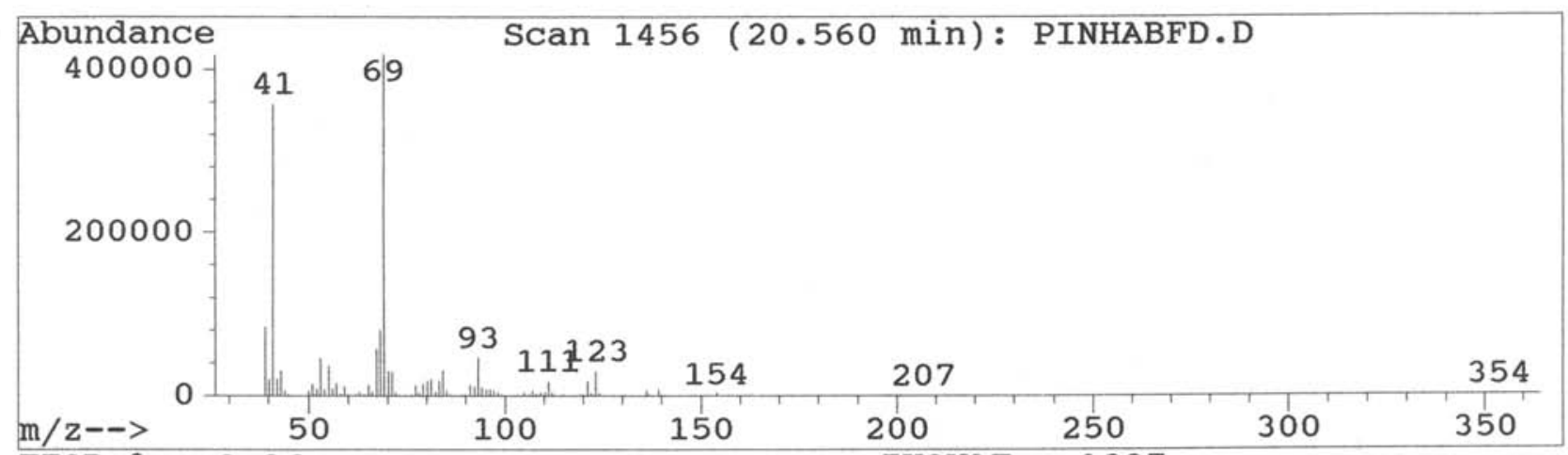

TEOR \% $=0.96$

IKOVAT $=1237$

Figure S11. Mass spectra of geraniol.

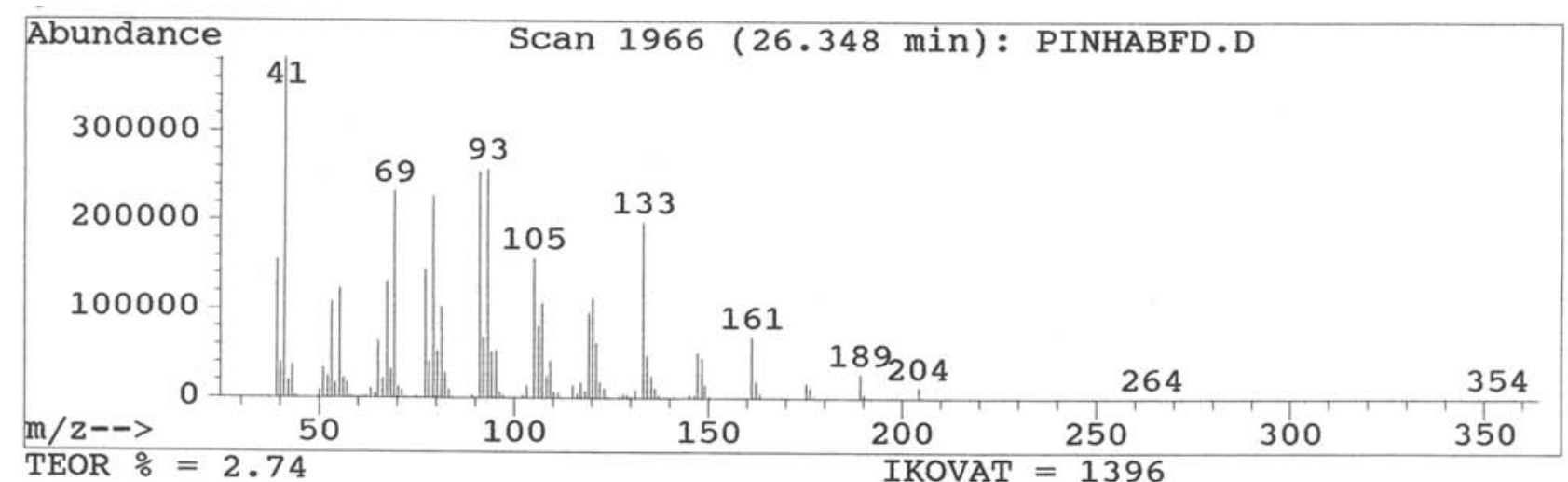

Figure S12. Mass spectra of $\beta$-caryophyllene.

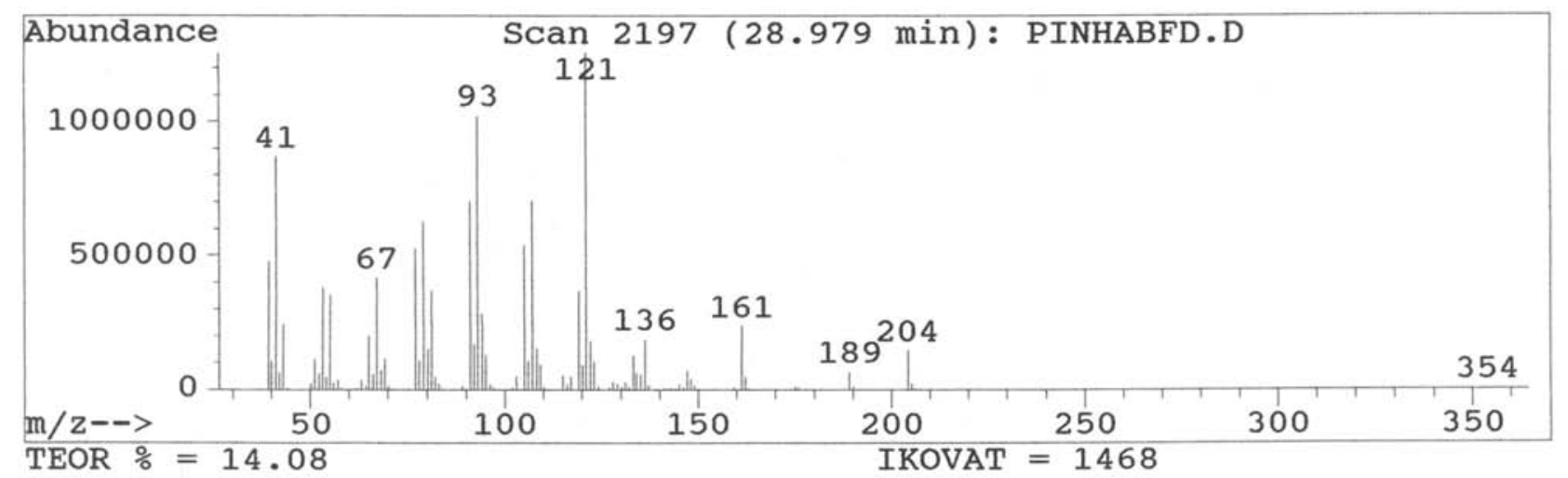

Figure S13. Mass spectra of bicyclogermacrene. 


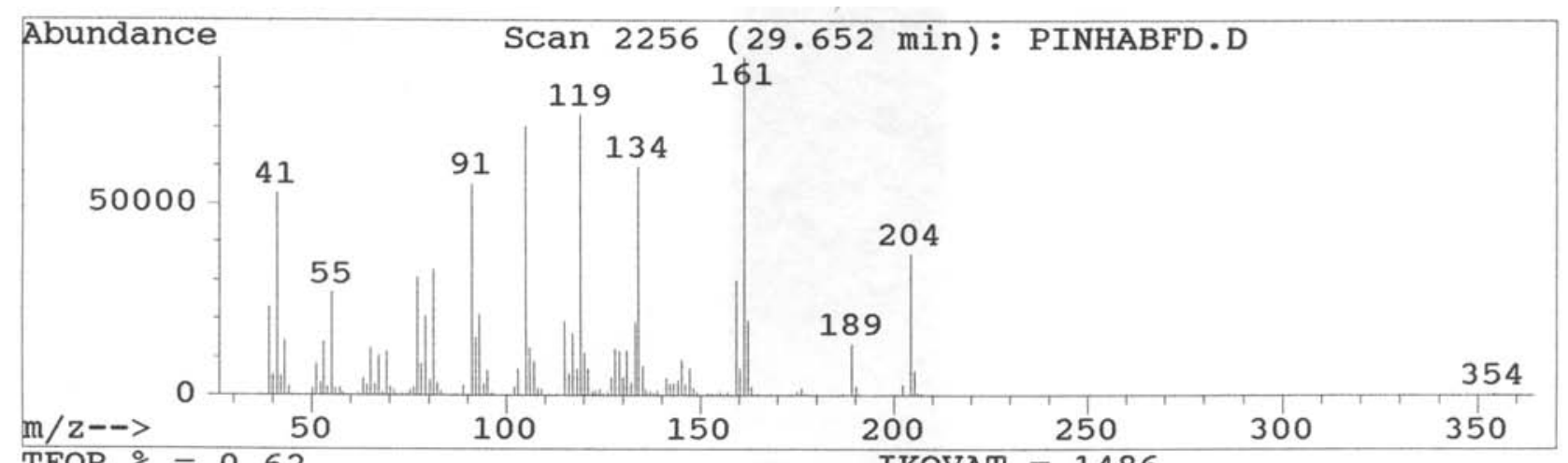

TEOR $\%=0.62 \quad$ IKOVAT $=1486$

Figure S14. Mass spectra of $\delta$-cadinene.

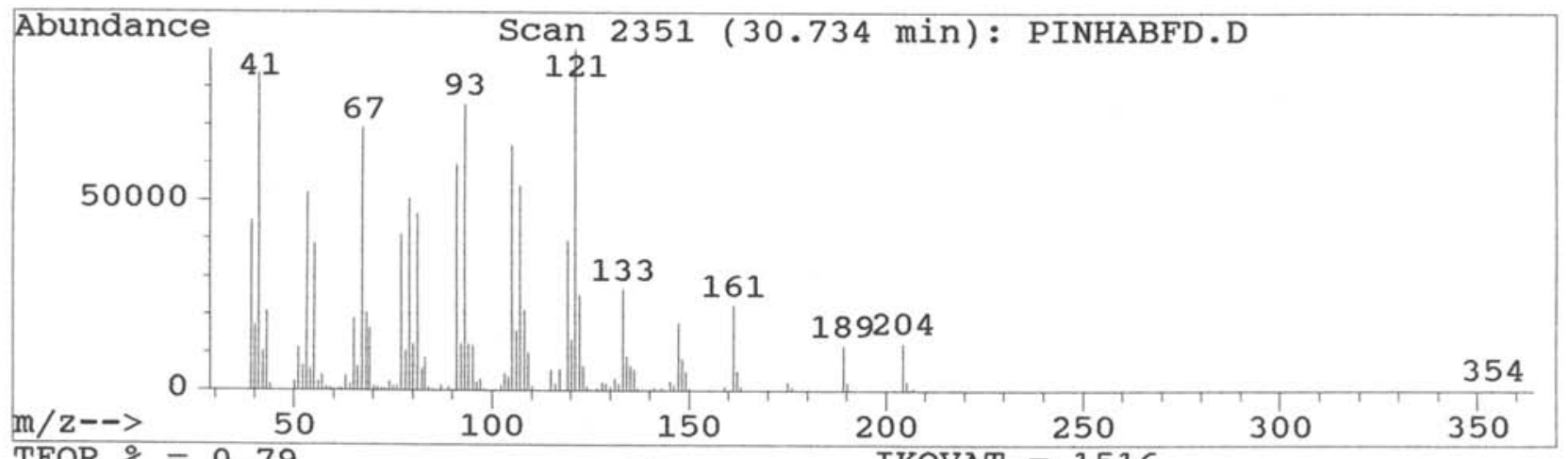

TEOR \% $=0.79$ IKOVAT $=1516$

Figure S15. Mass spectra of germacrene B.

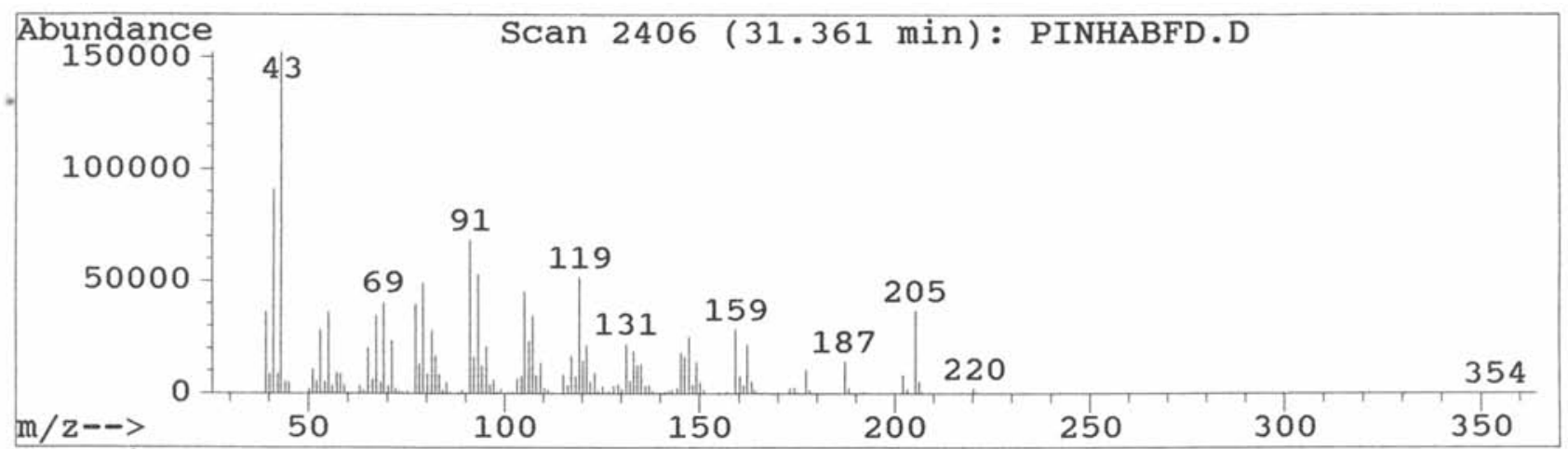

TEOR \% $=0.92$ IKOVAT $=1533$

Figure S16. Mass spectra of spathulenol. 


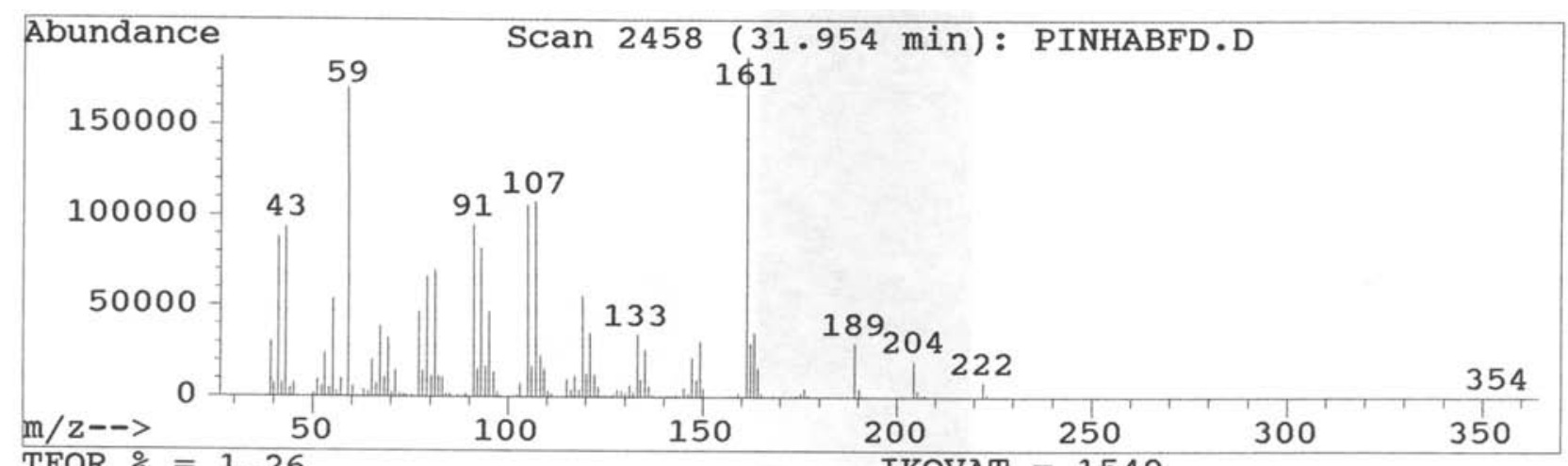

TEOR $\%=1.26 \quad$ IKOVAT $=1549$

Figure S17. Mass spectra of guaiol.

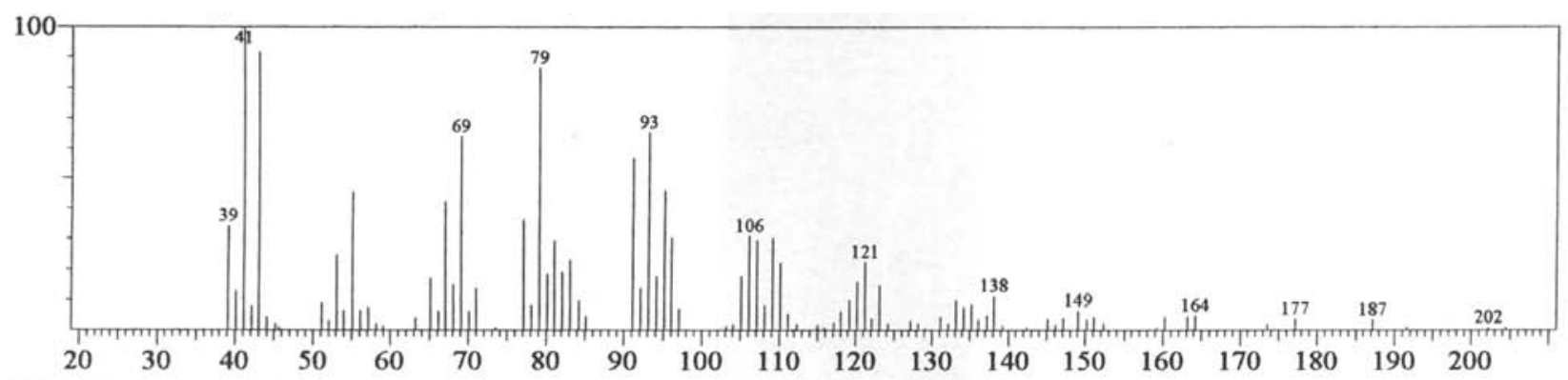

Figure S18. GC-MS chromatogram of the essential oil from stem bark of Rollinia leptopetala.

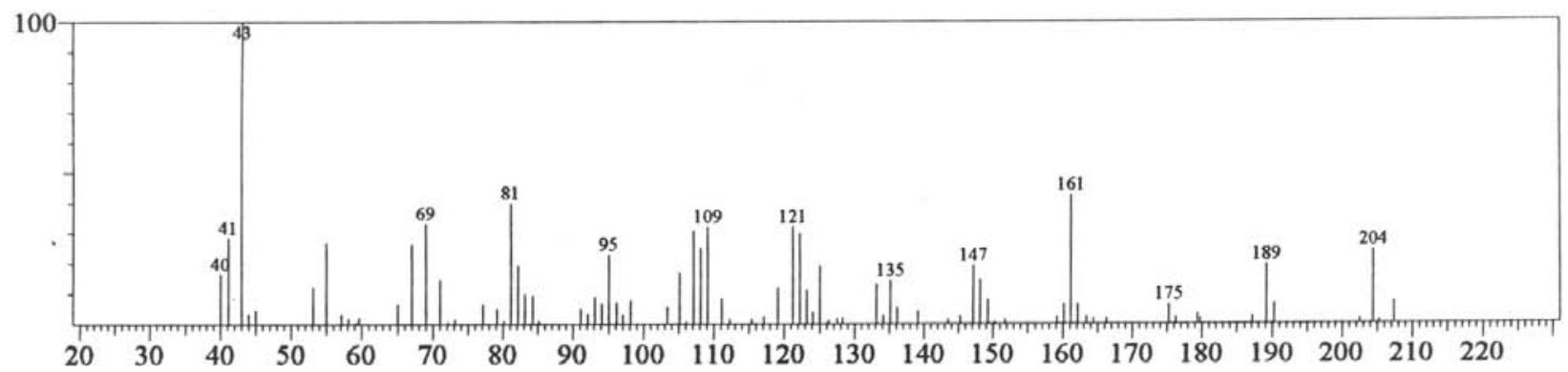

Figure S19. Mass spectra of caryophyllene oxide.

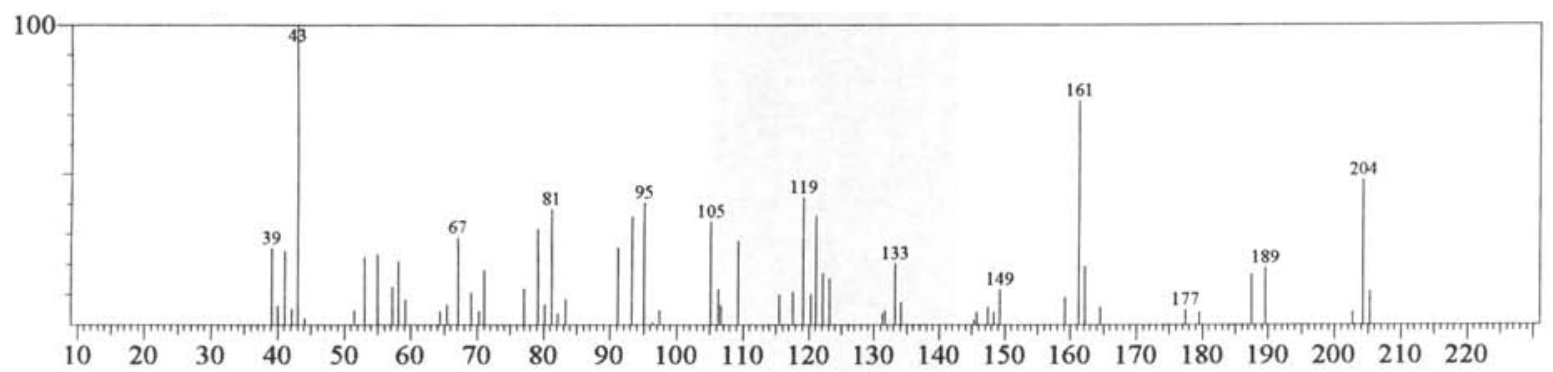

Figure S20. Mass spectra of globulol. 


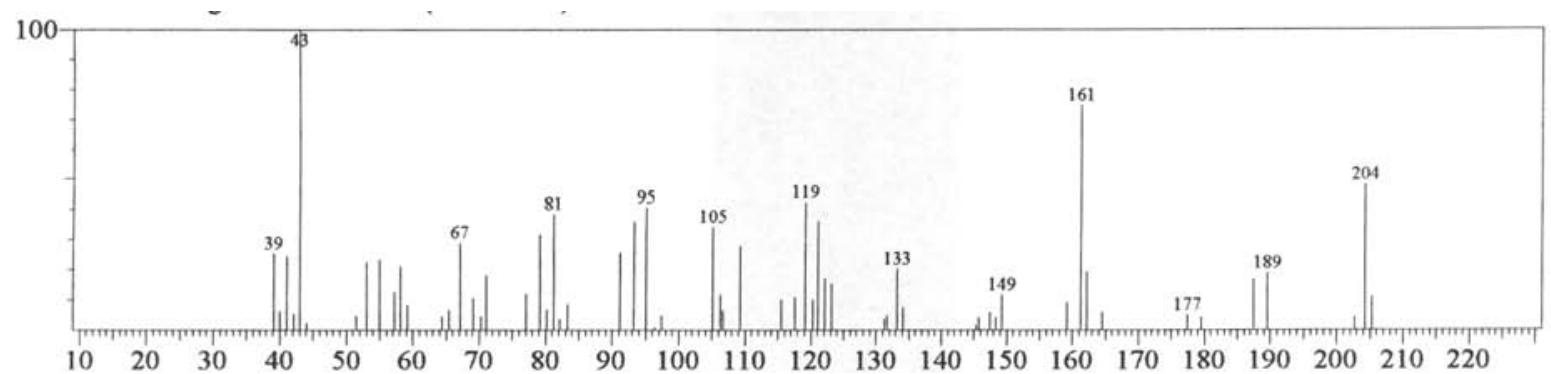

Figure S21. Mass spectra of epi- $\alpha$-muurolol.

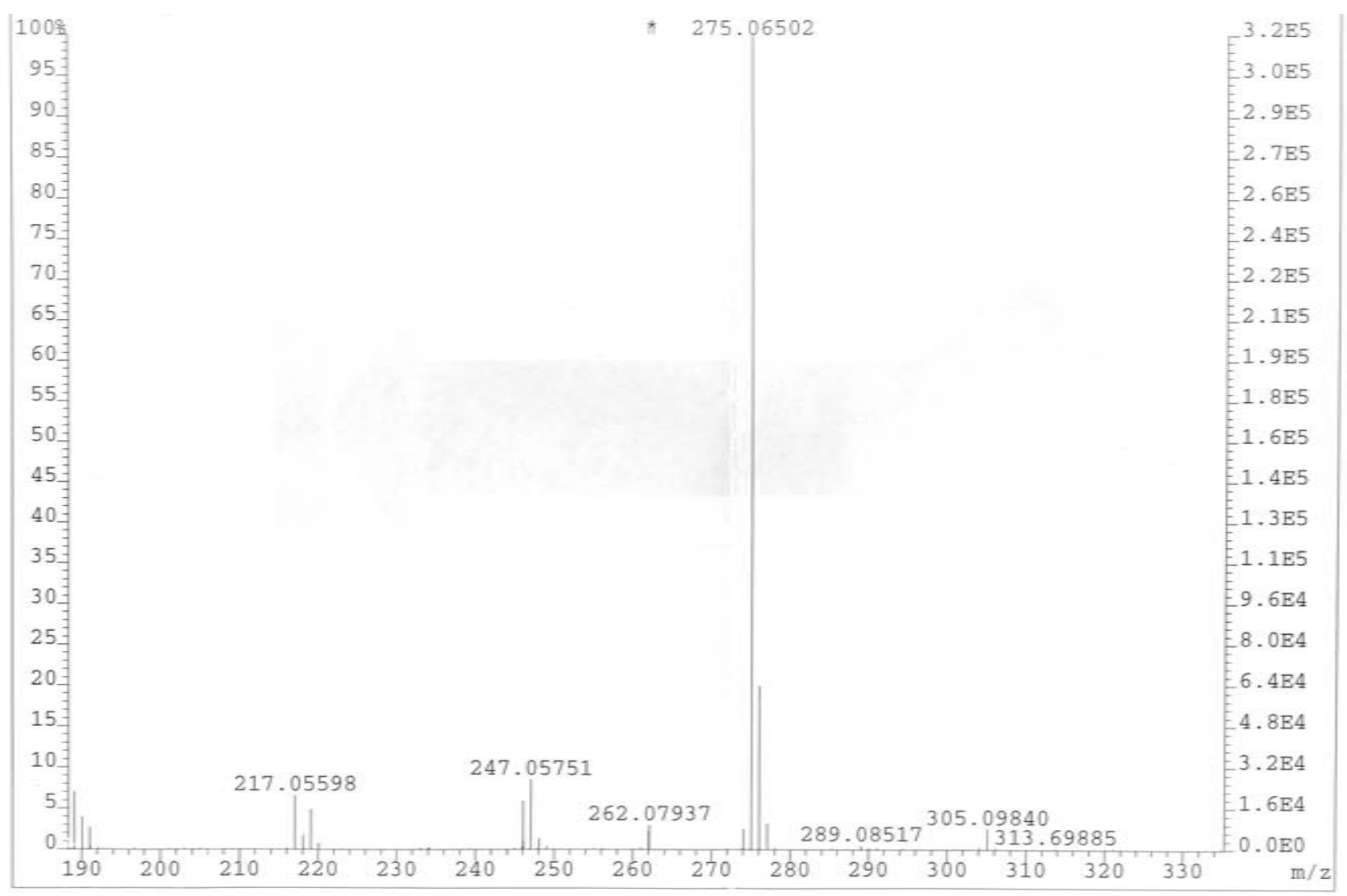

Figure S22. Mass spectra obtained by eletronic impact (EI) of compound (1) isolated from roots of Rollinia leptopetala. 


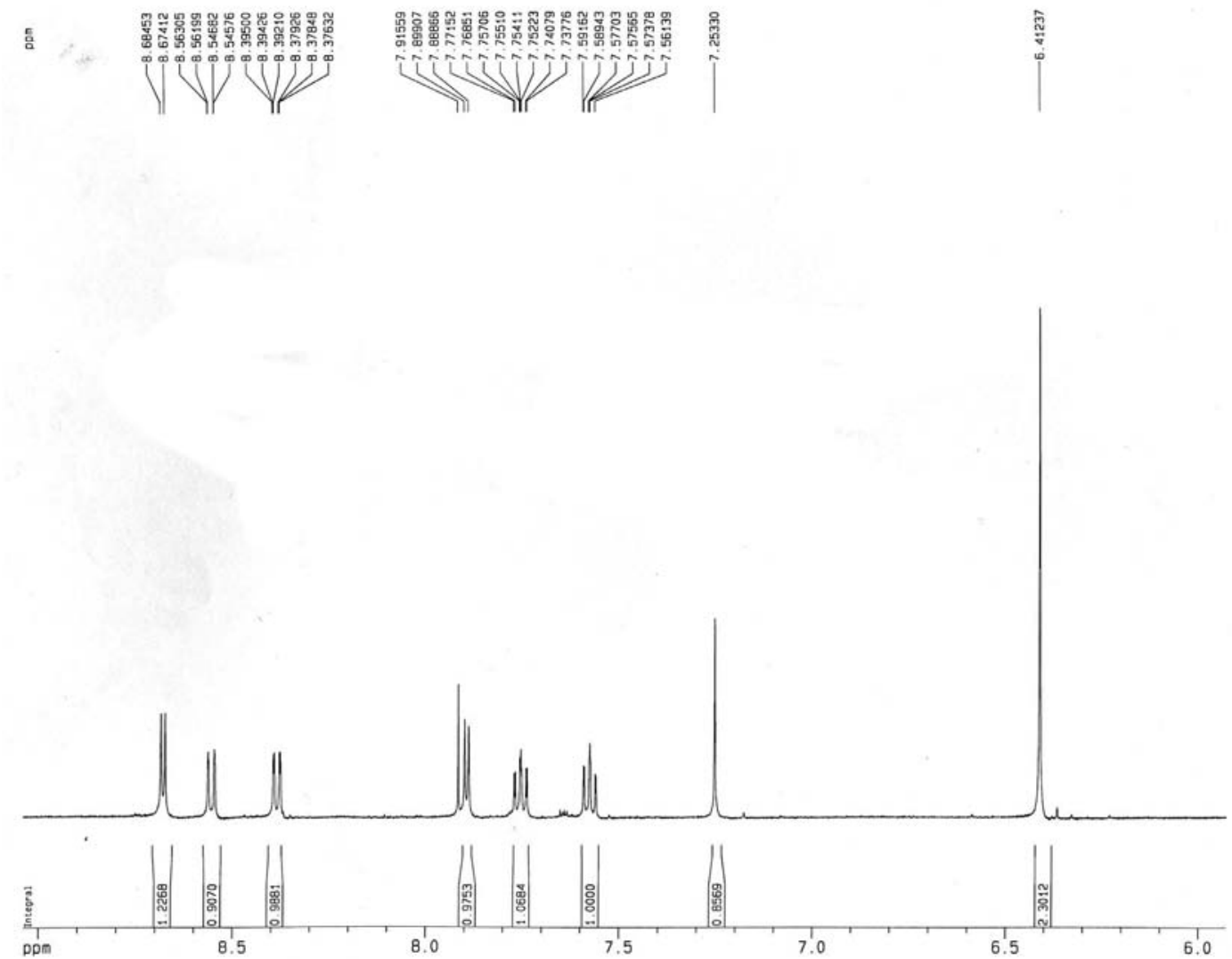

Figure S23. ${ }^{1} \mathrm{H}$ NMR spectrum (in $\mathrm{CD}_{3} \mathrm{OD}, 500 \mathrm{MHz}$ ) of compound (1) isolated from roots of Rollinia leptopetala.

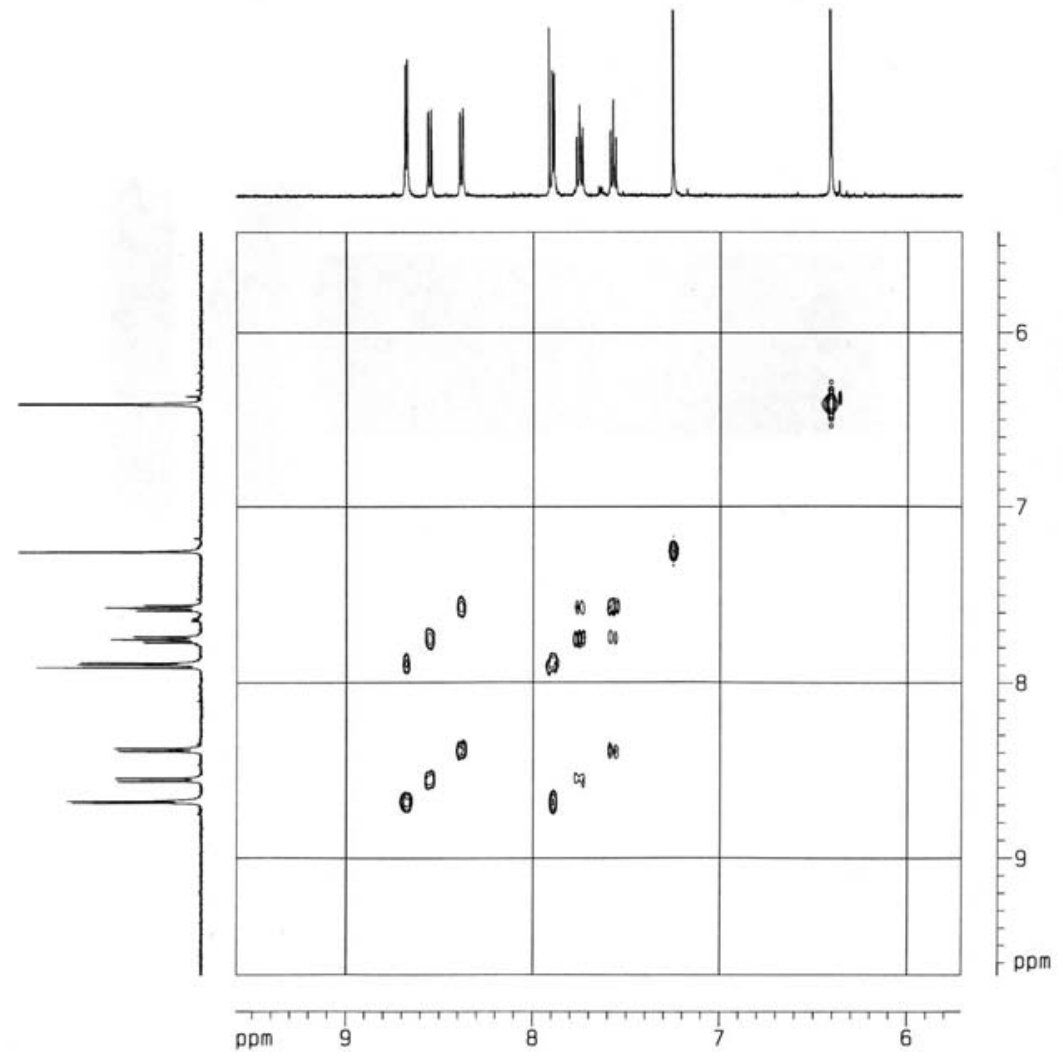

Figure S24. gCOSY NMR experiment (in $\mathrm{CD}_{3} \mathrm{OD}, 500 \mathrm{MHz}$ ) of compound (1) isolated from roots of Rollinia leptopetala. 


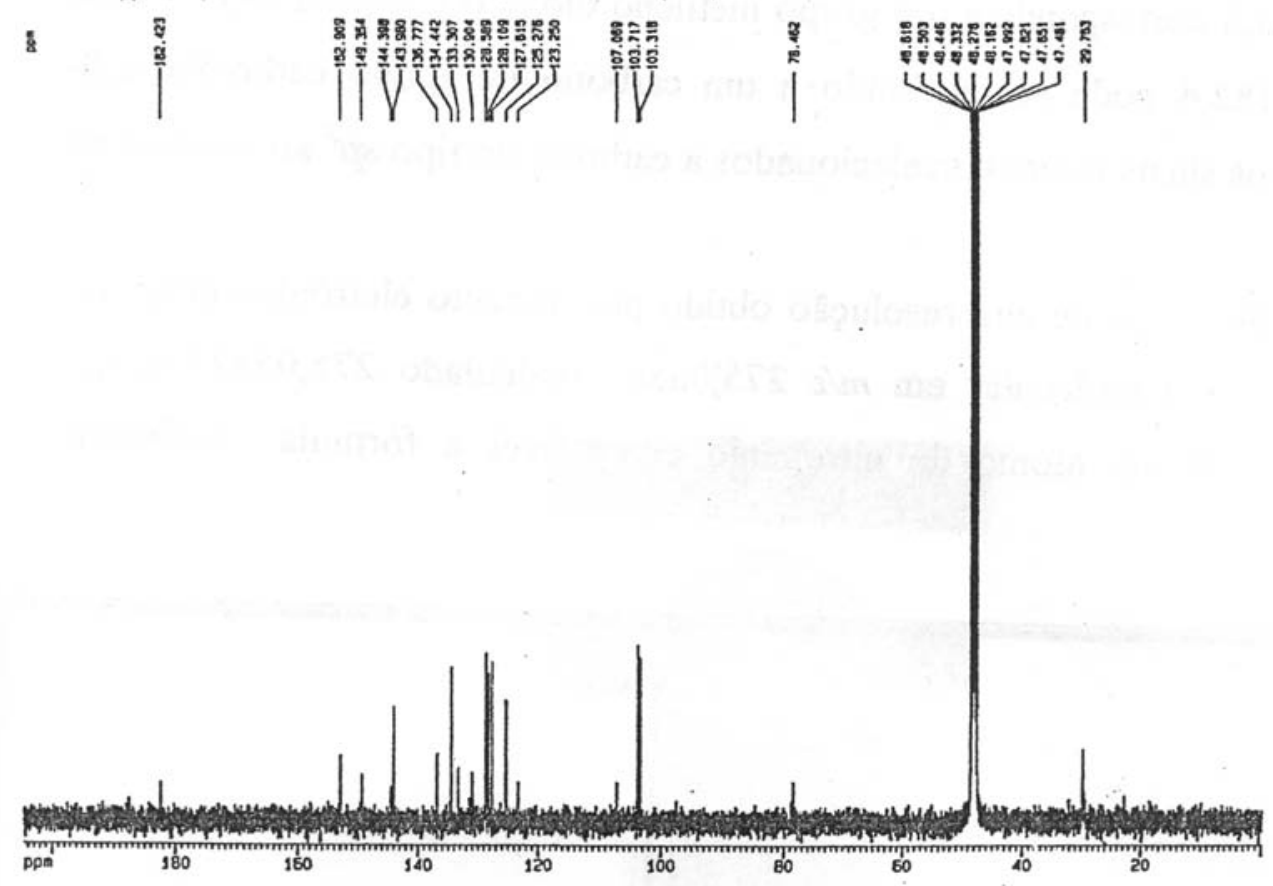

Figure S25. ${ }^{13} \mathrm{C}$ NMR spectrum (in $\mathrm{CD}_{3} \mathrm{OD}, 125 \mathrm{MHz}$ ) of compound (1) isolated from roots of Rollinia leptopetala.

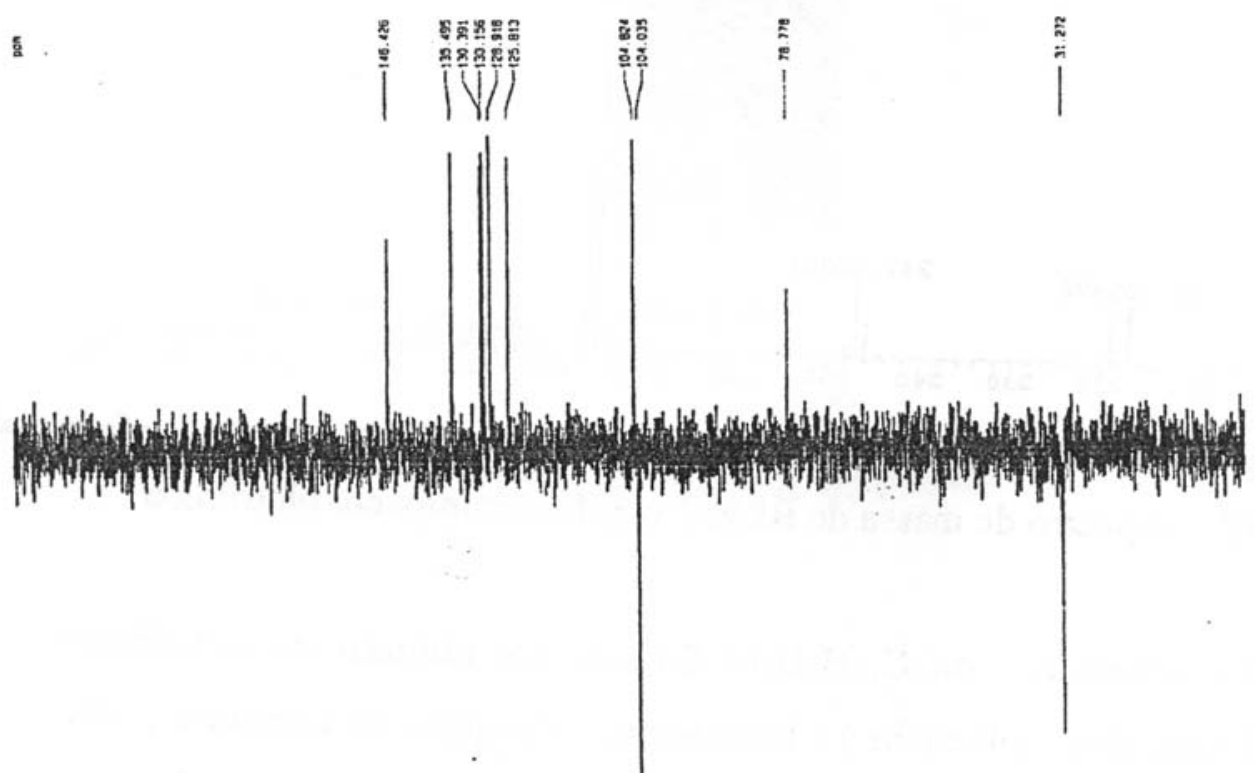

Figure S26. DEPT NMR experiment (in $\mathrm{CD}_{3} \mathrm{OD}, 125 \mathrm{MHz}$ ) of compound (1) isolated from roots of Rollinia leptopetala. 

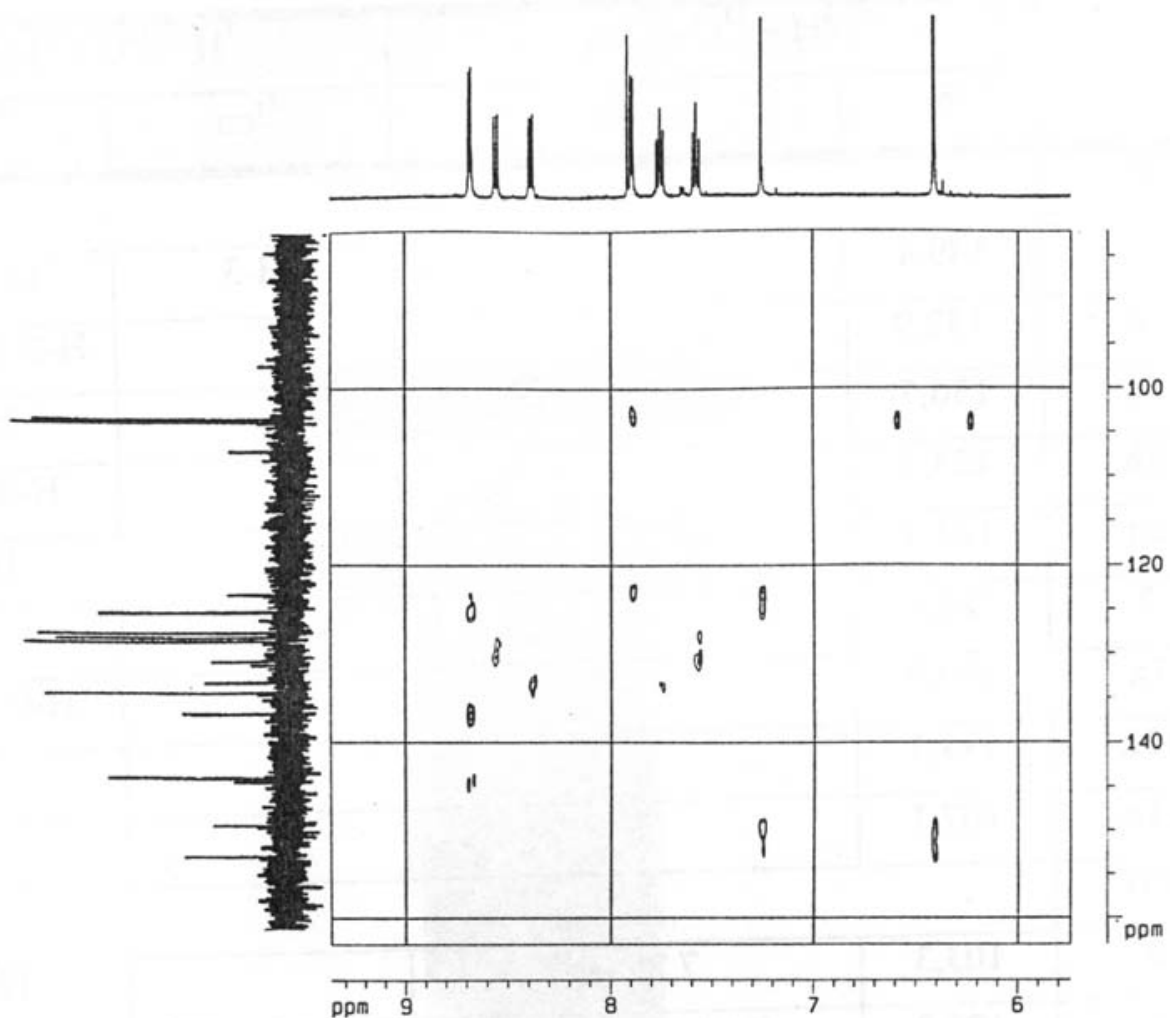

Figure S27. HMBC NMR experiment (in $\mathrm{CD}_{3} \mathrm{OD}, 500 \times 125 \mathrm{MHz}$ ) of compound (1) isolated from roots of Rollinia leptopetala.

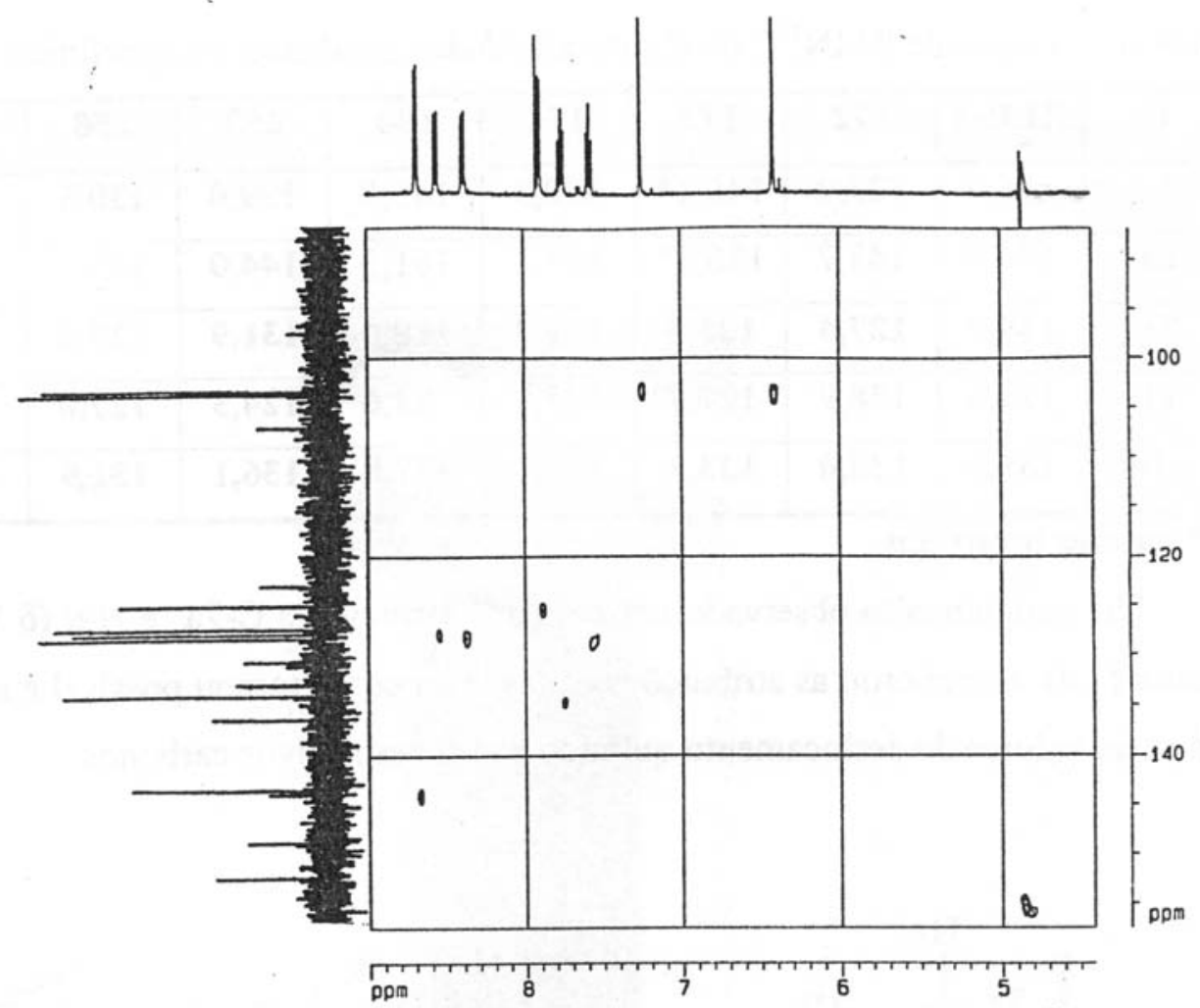

Figure S28. HMQC NMR experiment (in $\mathrm{CD}_{3} \mathrm{OD}, 500 \times 125 \mathrm{MHz}$ ) of compound (1) isolated from roots of Rollinia leptopetala. 